\title{
Impact of Exchange Rate Devaluation in Ethiopia and Forecasting Foreign Exchange Rate Using ARIMA Model
}

\author{
Tadele Alamneh (PhD Candidate in Economics) \\ College of business and economics, Debre Markos University, Debre Markos, Ethiopia \\ Malebo Mancha $(\mathrm{PhD})$ \\ College of business and economics, Arba Minch University, Arba Minch, Ethiopia
}

\begin{abstract}
The exchange rate is an important indicator of economic activity that policymakers use to formulate policies. This paper is based on fitting historical nominal exchange rate time series expressed in terms of past values of itself plus current and lagged values of error term using the Autoregressive Integrated Moving Average (ARIMA) model over the period 1971-2020, resulting in the model $(2,1,1)$ to forecast the next 15 years. The projection's performance is assessed using data from the preceding fifty years sourced from World Bank, and the forecast indicates that domestic currency depreciation will become more prevalent in order to stimulate exports. Moreover, the ARDL model is used to examine the impact of exchange rate, import, export, and inflation rate on RGDP from 1977 to 2018. The unit root test (Augmented Dickey- Fuller test) was used to verify the integration order of the variables. The five variables are used in the cointegration analysis. The bounds test of cointegration was used in this work. The results showed that the F-statistics value is greater than the upper boundaries at all levels of significance, indicating that individual variables have a long-term relationship with RGDP. This led to the estimation of the Error Correction Model (ECM), in which 25.1 percent of the disequilibrium is adjusted annually to bring the system back into equilibrium. Furthermore, nominal exchange rate and import has positive contribution to RGDP while inflation has adverse effect on RGDP in the long-run. Besides, inflation has a negative impact to RGDP in the short run due to its lag period effects.
\end{abstract}

Keywords: forecasting, ARIMA model, ARDL model

DOI: $10.7176 / \mathrm{EJBM} / 13-17-02$

Publication date:September $30^{\text {th }} 2021$

\section{INTRODUCTION}

\subsection{Background}

Every nation has three economic goals to attain both in the short and in the long run, these are achieving economic growth, creating more employment and having no or minimum inflation simultaneously. In order to achieve these goals and make their countries better off, countries use monetary and fiscal policies as a strategy and let their nation's aggregate demand curve to shift either to the right- or left- side. The most common economic policy instruments used by governments to monitor and change their economies are fiscal and monitory measures. Fiscal policy is all about letting the government to collect taxes and spend it on public sectors like infrastructures, education and so on and which mainly focuses only on the domestic economy whereas, monetary policy deals with both domestic and international economy. Meaning, the government can use monetary policy and the exchange rate policy of devaluation in order to affect the domestic and international markets respectively (Fratzscher et al, 2014).

Despite the fact that both policies appear to effect seemingly unrelated markets, it has been proved that combining them considerably helps in determining the level of production. The trade balance, net international capital movement, and other macroeconomic events are all influenced by a country's exchange rate policy. With daily trade volumes in the hundreds of millions of dollars, the foreign exchange market is the most liquid financial market (Eun and Resnick, 2018).

Many developing countries' currencies are widely agreed to be "over-valued". Even when the indicators of over-valuation are clear, most countries are reluctant to devalue their currencies. There are a variety of reasons cited for not devaluing, however, the majority of them allude to

Three main points: 1) Devaluation will not improve the payments position of the devaluing country; 2) devaluation may work if given a chance, but it will unleash forces in the economy that will eventually undercut its benefits and those of other economic policies; and 3) even if devaluation works, it will be politically disastrous for those in charge.

Despite these sources of resistance, currency weakening or devaluation of one's own currency in terms of foreign currencies, has become a major source of growth in many countries, particularly in developing ones. Many development institutions, such as the International Monetary Fund (IMF) and the World Bank (WB) encourage devaluation as a way of economic growth in addition to financial aid and loans to their member countries for domestic firm development. It will enhance firm competitiveness, increase domestic product and output production; 
and provide them a competitive advantage in bilateral and multilateral trade with their partners. However, some researchers focusing on developing countries (Krugman \& Taylor, 1978; Ahmad et al, 2018; Barguellil, Ben-Salha, and Zmami, 2018; Umaru and Davies, 2018) shed light on the negative effect of devaluation on output. Despite ambiguous results from empirical studies, devaluation of currency has been used as a growth strategy by many developing countries.

Ethiopia, a Sub-Saharan African country, is classified as one of the world's least developed countries. Many reasons contribute to the country's poor economic development. In the previous two decades, policies such as institutional development, privatization of the public sector, and currency devaluation have been implemented to achieve long-term economic growth (Beakal T., 2019). During the Ethiopia People Revolutionary Democratic Front (EPRDF) rule, the Ethiopian Birr (ETB) was devalued against the US dollar. Previously, the country had a fixed exchange rate of 2.07 Birr for every US dollar. According to some scholars, the birr was overvalued throughout the 1970s and 1980s, resulting in a trade and public budget deficit. According to Kidane (1994), currency overvaluation was the outcome of a management failure. The overvaluation of the currency hindered both export and local production by making imported goods cheaper. Furthermore, there was a scarcity of exchange rates, and only a few people were able to participate in the market.

As a result of the foreign exchange over-valuation and unavailability, the unofficial or parallel exchange rate began to spread in the country. The unofficial rate peaked at 6 or 7 birr per US dollar in mid-1980, while the official rate remained at 2.07 birr per US dollar. Taking this into account, Ethiopia's transitional government decided to devalue the currency to 5 birr per US dollar in 1992. The devaluation of the currency was intended to boost output by stimulating exports while also increasing local production (Taye, 1999; Beakal, 2019).

After the devaluation in 1992, the exchange rate is changed from fixed to flexible rate in order to control overvaluation through a gradual depreciation of domestic currency every year. The gap between the parallel and official rate also decreased compared to the period when the exchange rate was fixed. However, during the fiscal year 2007/08 the rate of depreciation against other foreign currencies increased compared to the previous years. In the 2009/10 and September, 2010/2011 the Ethiopian Birr was devalued to $23.7 \%$ and $16.5 \%$ respectively against the US dollar. On October 10, 2017 the National Bank of Ethiopia (NBE) devalued the Birr by 15 percent as pressures on the foreign exchange intensified. This huge devaluation was expected to "decrease overvaluation and increase competitiveness" (IMF, 2010; MOFED, 2009). According to the government, the devaluation was conducted to encourage exports and alleviate a foreign exchange shortfall (Ayen, 2017). Generally, the country's exchange rate has fluctuated during the last two decades, and the future is expected to do so as well.

As though uncertainty is inescapable, every economic decision appears to be based on accurate predictions. Despite the increasing turbulence of the foreign exchange rate regime, there has been an increase in interest in forecasting the succeeding eras of exchange rate. Exchange rate fluctuations are extremely complex, chaotic, and noisy. It affects foreign reserves, currency values, company's operational profitability, and the country's balance of payments, among other factors. The foreign exchange rate fluctuates on a daily basis due to shifting market dynamics of demand and supply. Foreign direct investment (FDI), the price of goods and services, interest rates, the balance of payments, government foreign exchange guidelines, Money demand and supply, the country's export and import, political and psychological factors, recession, and speculation all influence the exchange rate (Barguellil et al., 2018).

Forecasting exchange rates is essential by central banks in order to carry out the country's forex policy. Forecasting is equally important for speculators and hedgers when it comes to risk management. Forecasting exchange rate swings can impact the overall consolidated financial balances of large multi-national corporations (MNCs) who have greater inflows and outflows of foreign exchange as their commercial activities.

Given the importance of the foreign exchange market, practitioners and corporations will be interested in conducting a forecasting study in order to formulate policies accordingly. As a result, this study outperforms in terms of providing a comprehensive picture based on real-world data from Ethiopia, forecasting foreign exchange rate and assessing its impact on economic growth.

\section{2. Rationale of the study}

Ethiopia implemented the structural adjustment program (SAP) in 1992 in response to the World Bank and IMF's demands for reforms that they suggest for developing countries in order for them to be eligible for loans if certain requirements are met. One of the SAP's requirements for implementing these policies is that less developed countries that face balance of payment problems as a result of expansionary financial policies, deterioration in trade, price distortions, high debt servicing, or a combination of these factors must devalue their currencies (Nashashibi, 2013). Ethiopia suffered a number of issues, including those described above and others, that contributed to the country's low external trade performance. Even though there were many and varied reasons for low economic performance, inadequate macroeconomic policies were the most common. As a result, for reliable and ongoing growth and development, as well as to maintain the country's external and internal balance, comprehensive, compatible, timely, and sequential policy restructuring was unquestionable. To accomplish so, 
Ethiopia has implemented several policy and structural changes on both micro and macro levels of the economy, such as the Structural Adjustment Program (SAP) which began after the fall of the Derg regime. As part of these general reform effort, on October 1, 1992, the Ethiopian Birr was devalued from its nominal level of 2.07 Birr per US dollar to 5.00 Birr per US dollar (Befikadu and Kibre, 1994).

Although devaluation is meant to improve the trade balance by promoting exports, there are theoretical distinctions in how exchange rates affect economic growth. Economic adjustment programs for less developed countries often focus on domestic absorption through restrictive monetary and fiscal policies, as well as expenditure switching (i.e., increased tradables production) through currency devaluation. If there is unutilized capacity, a nominal devaluation leads in higher output, according to classical theory. As a result, devaluation raises the relative prices of tradables and non-tradables, encouraging expenditure switching (Nguyen, 2014; Moller and Walker, 2015; Agus and Long, 2018).

However, the traditional view that devaluation-induced expenditure switching provides an important stimulus to economic growth has come under serious attack. Various theoretical arguments are advanced that point to contractionary effects of devaluations. Earlier studies mainly refer to adverse demand effects. The re-distribution of income in favour of profits and at the expense of wages, supposed to follow a devaluation, may depress economic activity because of the higher marginal propensity to consume of wage earners (Diaz Alejandro, 1963; Krugman, Taylor, 1978) and this theoretical foundation is substantiated by empirical findings of various scholars where exchange rate has adverse effect on economic growth since devaluation is likely to result in a higher domestic price level, aggregate demand and output may be reduced as a result of a negative real balance effect (Pigou effect) (Ahmad A. et al, 2018; Barguellil et al, 2018 ; Umaru and Davies, 2018).

As a result, these theoretical and empirical divergences have yet to be harnessed, and development practitioners are in desperate need of an empirical investigation. Therefore, the rationale of this paper is to pleat empirical information on the impact of foreign exchange rate of Ethiopian economic growth.

\subsection{Objective of the study}

The general objective of this seminar is to forecast the foreign exchange rate and assess its impact on Ethiopian economic growth, based on the foregoing theoretical and empirical foundations of the background setting.

Specific objectives include:

$>$ Forecasting a 15-year Ethiopian foreign exchange rate for the period 2021 to 2035.

$>$ Assessing the impact of foreign exchange rate on Ethiopia's economic growth.

\section{METHODOLOGY}

This study had used yearly data from 1977 to 2018 for the macro variables that are supposed to analyze the impact of exchange rate on economic growth; and for the purpose of forecasting foreign exchange rate, the data spans from 1971 to 2020. The data was taken from World Bank and National Bank of Ethiopia. The parameters employed in the study to analyze the impact of foreign exchange rate on economic growth are, Real Gross Domestic Product (RGDP) which is a proxy for economic growth, and independent variables that are included in this study are nominal exchange rate, the total value import of goods and services, the total value of export items and the inflation rate. The estimation was performed using the auto regressive distributive lag (ARDL) model where as for the purpose of forecasting foreign exchange rate is auto regressive integrated moving average (ARIMA) model was employed. The data was analyzed with the help of EViews 10. The model of estimating the impact of exchange rate on economic growth is stated as follows:

\section{$L n R G D P=\beta_{0}+\beta_{1} \operatorname{LnNEXR}+\beta_{2}$ LnIMPORT $+\beta_{3} \operatorname{LnEXPORT}+\beta_{4}$ INFLATION $+\varepsilon$}

Where $\mathrm{B}_{0}, \beta_{1}, \beta_{2}, \beta_{3}, \beta_{4}$ are coefficients. RGDP is the real gross domestic product that indicates Ethiopia's economic growth and is expressed as a dependent variable. The independent variable is: NEXR is the nominal exchange rate IMPORT is the total value of imported goods and service, EXPORT is the total value of goods and services of export GDP, INFLATION is the rate of inflation calculated using the consumer price index and $\varepsilon$ is the error item.

\subsection{ARIMA Models}

The Box-Jenkins (ARIMA) model is in theory the most general class of models for forecasting time series and was first popularized by Box and Jenkins (1970). ARIMA (p, d, q) completely ignores independent variables and assumes that past values of the series plus previous error terms contain information for the purposes of forecasting. The integers refer to the Autoregressive (AR), Integrated (I) and Moving Average (MA) parts of the data set respectively. The models are applied in some cases on data which show evidence of non-stationarity which can be stationarized by transformations such as differencing and logging. The model takes into account historical data and decomposes it into AR process, where there is a memory of past events; an integrated process, which accounts for stationarity, making it easier to forecast; and MA of the forecast errors, such that the longer the historical data, the more accurate the forecasts will be, as it learns over time. The ARIMA models are applicable only to a stationary data series, where the mean, the variance, and the autocorrelation function remain constant through time. 
Autoregressive process AR expresses a dependent variable as a function of past values of the dependent variable. A $\mathrm{P}^{\text {th }}$ - order process is of the form:

$\mathbf{y}_{\mathrm{t}}=\alpha+\emptyset_{1 \mathbf{y}_{\mathrm{t}-1}}+\emptyset_{2 \mathrm{yt}-2}+\ldots \ldots \ldots \ldots \ldots \ldots \ldots \ldots \ldots \ldots+\emptyset_{\mathrm{p}} \mathbf{y}_{\mathrm{t}-\mathrm{p}}+\mathbf{\varepsilon}_{\mathrm{t}}$

Where; $\mathrm{Yt}$ is the stationary depended variable being forecasted at time $\mathrm{t}, \mathrm{y}_{\mathrm{t}-1}, \mathrm{y}_{\mathrm{t}-2}, \ldots . ., \mathrm{y}_{\mathrm{t}-\mathrm{p}}$ is the response variable at time lags $\mathrm{t}-1, \mathrm{t}-2, \ldots . \mathrm{t}-\mathrm{p}$ respectively.

$$
\boldsymbol{\alpha}=\mu\left(1-\emptyset_{1-\ldots . .-} \emptyset_{\mathrm{p}}\right),
$$

$\emptyset_{1}, \emptyset_{2}, \ldots \ldots \emptyset \mathrm{p}$ are the coefficients to be estimated.

$\varepsilon_{t}$ is the error term at time $t$ with mean zero and constant variance.

Using the backshift operator, we can write the $\mathrm{AR}(\mathrm{p})$ model as;

$$
\left(1-\emptyset_{1} \beta-\emptyset_{2} \beta^{2}-\cdots \cdots-\emptyset_{\mathrm{p}} \beta^{\mathrm{p}}\right) \mathrm{y}_{\mathrm{t}}=\varnothing(\mathrm{B}) \mathrm{y}_{\mathrm{t}}=\varepsilon_{\mathrm{t}}
$$

The moving average model of order $\mathrm{MA}(\mathrm{q})$ is defined as;

$$
\mathrm{Y}_{\mathrm{t}}=\varepsilon_{\mathrm{t}}+\theta_{1} \varepsilon_{\mathrm{t}-1}+\theta_{2} \varepsilon_{\mathrm{t}-2}+\cdots \cdots+\theta_{\mathrm{q}} \varepsilon_{\mathrm{t}-\mathrm{q}}
$$

Where; $q$ is the number of lags in the moving average and $\theta_{1}, \theta_{2} \ldots \ldots . \theta q$ are parameters to be estimated. The moving average operator is given by;

$$
\theta(\beta)=\theta_{1} \beta+\theta_{2} \beta^{2}+\cdots \cdots+\theta_{\mathrm{q}} \beta^{\mathrm{q}}
$$

To create an ARMA model, we begin with an econometric equation with no independent Variables $Y_{t}=\beta_{0}+\varepsilon_{t}$ and add to it both the AR process and the MA process.

$$
\mathrm{y}_{\mathrm{t}}=\beta_{0}+\emptyset_{1} \mathrm{y}_{\mathrm{t}-1}+\emptyset_{2} \mathrm{y}_{\mathrm{t}-2}+\cdots \cdots+\emptyset_{\mathrm{p}} \mathrm{y}_{\mathrm{t}-\mathrm{p}}+\varepsilon_{\mathrm{t}}+\theta_{1} \varepsilon_{\mathrm{t}-1}+\theta_{2} \varepsilon_{\mathrm{t}-2}+\cdots \cdots+\theta_{\mathrm{q}} \varepsilon_{\mathrm{t}-\mathrm{q}}
$$

$\beta_{0}+\emptyset_{1} \mathrm{y}_{\mathrm{t}-1}+\emptyset_{2} \mathrm{y}_{\mathrm{t}-2}+\cdots \cdots+\emptyset_{\mathrm{p}} \mathrm{y}_{\mathrm{t}-\mathrm{p}}$ is the AR (p), and $\theta_{1} \varepsilon_{\mathrm{t}-1}+\theta_{2} \varepsilon_{\mathrm{t}-2}+\cdots \cdots+\theta_{\mathrm{q}} \varepsilon_{\mathrm{t}-\mathrm{q}}$ is the MA(q) process. Where the $\emptyset^{\prime}$ 's and $\theta$ 's are the coefficients of the autoregressive and moving average processes respectively.

The integrated ARMA or ARIMA model is a broadening class of ARMA model which includes a differencing term. A process is said to be ARIMA (p, d, q) if: $\nabla^{\mathrm{d}} \mathrm{yt}=(1-\mathrm{B})^{\mathrm{d}} \mathrm{y}_{\mathrm{t}}$ is an ARIMA $(\mathrm{p}, \mathrm{q})$. This is generally written as;

$$
\emptyset(\mathrm{B})(1-\mathrm{B})^{\mathrm{d}} \mathrm{y}_{\mathrm{t}}=\theta(1-\mathrm{B}) \varepsilon_{\mathrm{t}}
$$

A first- differenced exchange rate series is of the form:

$$
\mathrm{NEXR}_{\mathrm{t}}=\left(\nabla N E X R_{\mathrm{t}}\right)=\mathrm{NEXR}_{\mathrm{t}}-\mathrm{NEXR}_{\mathrm{t}-1}=\Delta \mathrm{NEXR}_{\mathrm{t}}-\Delta \mathrm{NEXR}_{\mathrm{t}-1}
$$

Thus, the ARIMA (p, 1, q) model may be specified as:

NEXRt $=\beta_{0}+\emptyset_{1} \mathrm{NEXR}_{\mathrm{t}-1}+\emptyset_{2} \mathrm{NEXR}_{\mathrm{t}-2}+\cdots+\emptyset_{\mathrm{p}} \mathrm{NEXR}_{\mathrm{t}-\mathrm{p}}+\varepsilon_{\mathrm{t}}+\theta_{1} \varepsilon_{\mathrm{t}-1}+\theta_{2} \varepsilon_{\mathrm{t}-2}+\cdots+\theta_{\mathrm{q}} \varepsilon_{\mathrm{t}-\mathrm{q}} \quad$ (2.10)

Where NEXRt, is the differenced nominal exchange rate series of order 1 , and $\emptyset, \theta, \beta$ are the parameters to be estimated (Shumnay \& Stoffer, 2011).

The equation must assume stationarity before applying to a time series. In case of non-stationarity successive differences are taken until the series is stationary. In practice the differences are rarely more than two. The aim of this methodology is to find the most appropriate ARIMA (p, d, q) model and to use it for forecasting. It uses an iterative six-stage scheme:

i. A priori identification of the differentiation order $\mathrm{d}$ (or choice of another transformation);

ii. A priori identification of the orders $\mathrm{p}$ and $\mathrm{q}$;

iii. Estimation of the parameters $\left(\varnothing, \beta\right.$, and $\left.\theta, \delta^{2}=\operatorname{Var} \epsilon \mathrm{t}\right)$;

iv. Validation;

v. Choice of a model;

vi. Prediction.

\subsection{ARDL Model}

Cointegration method is used in the analysis of long-term relationships between variables. Engle and Granger (1987), Johansen and Juselius (1990) and Johansen (1991) are the most commonly used tests for testing cointegration. The Autoregressive Distributed Lag (ARDL) model and the bounds testing approach which is developed by Pesaran and Shin (1999) and Pesaran, Shin, and Smith (2001) has some advantages over other conventional cointegration approaches. Unlike the other cointegration methods, there is no limiting assumption that all variables used in the ARDL model should be integrated of the same order. Therefore, I (0) and I (1) variables can be used together. However, as a limiting condition, no variable should be integrated of the second or higher order. With this approach, problems arising from non-stationary series are largely eliminated. In addition, the variables included in the analysis may have different lag lengths which is not possible in the VAR modelling. Another advantage of the ARDL model is that short and long-term parameters can be estimated together. By applying linear transformation to the model, it makes possible to obtain an Error Correction Model that combines short-term and long-term relationships without losing long-term information. Another important advantage is that it can be applied to small samples. It gives consistent and reliable results even in samples with limited observations. LnRGDP $=\alpha+\beta_{1} \operatorname{lnREXR}+\beta_{2} \operatorname{lnIMPORT}+\beta_{3} \operatorname{lnEXPORT}+\beta_{4}$ INFLATION $+\varepsilon t$

Where GDP is the Real Gross Domestic Product, REXR is real exchange rate, EXPORT is the exports of goods and services, IMPORT is the import of goods and services, INFLATION is the rate of inflation adjusted for 
consumer price index. If we estimate the above equation by OLS or any other linear method, we obtain long-run effects of the explanatory variables on the explained variable (GDP). But the error correction modelling approach offers an opportunity to also estimate the short run effects. Moreover Pesaran et al., (2001) bounds testing approach has an advantage of estimating short-run and long-run effects in one step. Because of the mentioned advantages the ARDL model in equation (3.16) is estimated.

$\Delta$ LnRGDP $_{\mathrm{t}}=\alpha_{0}+\sum_{i=1}^{n 1} \cdot \alpha_{1 i} \Delta$ LnNGDP $_{\mathrm{t}-1}+\sum_{i=0}^{n 2} \cdot \alpha_{2 \mathrm{i}} \Delta \beta_{1} \operatorname{lnREXR}_{\mathrm{t}-1}+\sum_{i=0}^{n 3} \cdot \alpha_{3 i} \Delta \beta_{2} \operatorname{lnIMPORT}_{\mathrm{t}-1}+\sum_{i=0}^{n 4} \cdot \alpha_{3 \mathrm{i}} \Delta \beta 3$ $\sum_{i=0}^{n 5} . \alpha_{4 i} \Delta \beta_{3 \mathrm{i}} \operatorname{lnEXPORT}_{\mathrm{t}-1}+\sum_{i=0}^{n 6} . \alpha_{5 \mathrm{i}} \Delta \beta 4$ INFLATION $_{\mathrm{t}-1}+\lambda_{1} \operatorname{lnRGDP}_{\mathrm{t}-1}+\lambda_{2} \operatorname{lnREXR}_{\mathrm{t}-1}+\lambda_{3} \ln$ IMPORT $_{\mathrm{t}-1}+$ $\lambda_{4} \ln \operatorname{EXPORT}_{\mathrm{t}-1}+\lambda_{5}$ INFLATION $_{\mathrm{t}-1}+\varepsilon \mathrm{t}$

The coefficients from $\lambda_{1}$ to $\lambda_{5}$ show the long-run relationship between the variables and the coefficients from $\alpha_{1 \mathrm{i}}$ to $\alpha_{5 \mathrm{i}}$ showing the dynamic short run relationships among the variables. For example, the short-run effects of exchange rate on real RGDP are inferred by the estimates of $\alpha_{2 \mathrm{i}} . \Delta$ is the first difference operator, $\alpha_{0}$ is the constant and $\varepsilon_{\mathrm{t}}$ is the white noise error term.

The analysis of short and long-term dynamics with the ARDL bounds test approach requires a process consisting of several steps. In the first step, the above Model is estimated by OLS method and an F test is used to examine the long-run relationship between variables and test the coefficients of lagged variables together. The null hypothesis $\mathrm{H}_{0}: \lambda_{1}=\lambda_{2}=\lambda_{3}=\lambda_{4}=\lambda_{5}=0$ indicates that there is no long-term relationship or cointegration between variables.

The alternative hypothesis states that the lagged coefficients are significant and there is a cointegration relationship among them. The sample value of the calculated F statistic is compared with the critical upper and lower limits created by Pesaran et al., (2001). If the sample value of the calculated F statistic is less than the table lower bound, the null hypothesis stating that there is no cointegration is not rejected. However, if the sample value of the calculated F statistic is greater than the upper bound of the table, the null hypothesis is rejected and the existence of a long-run relationship between the variables in the model is determined. The test is inconclusive if the calculated F statistic is between the upper and lower bound.

After determining the cointegration relationship, in the second step, appropriate lag lengths for the variables are determined by using model selection criteria such as Hannan Quinn Criteria, Akaike Information Criteria (AIC), Schwarz Criteria (SBC). In the third step, by using the information from model (3.17) the error correction model is estimated.

$\Delta \mathrm{LnRGDPt}=\alpha_{0}+\sum_{i=1}^{n 1} \cdot \alpha_{1 i} \Delta \operatorname{LnRGDP}_{\mathrm{t}-1}+\sum_{i=0}^{n 2} \cdot \alpha_{2 \mathrm{i}} \Delta \beta_{1} \operatorname{lnREXR} \mathrm{RR}_{\mathrm{t}-1}+\sum_{i=0}^{n 3} \cdot \alpha_{3 \mathrm{i}} \Delta \beta_{2} \operatorname{lnIMPORT} \mathrm{TI}_{\mathrm{t}-1}+\sum_{i=0}^{n 4} \cdot \alpha_{3 \mathrm{i}} \Delta \beta 3$ $\sum_{i=0}^{n 5} \cdot \alpha_{4 \mathrm{i}} \Delta \beta_{3 \mathrm{i}} \operatorname{lnEXPORT} \mathrm{t}_{\mathrm{t}-1}+\sum_{i=0}^{n 6} \cdot \alpha_{5 \mathrm{i}} \Delta \beta 4$ INFLATION $_{\mathrm{t}-1}+\Phi \mathrm{ECM}_{\mathrm{t}-1}+\varepsilon_{\mathrm{t}}$

The coefficients from $\alpha_{1}$ to $\alpha_{5}$ are the short-term dynamic coefficients that stabilize the model. ECM is the error correction term and its coefficient $\phi$ shows the speed of adjustment of the model to the long - term equilibrium after a short - term shock. This coefficient should be negative and statistically significant.

For testing the stability of the estimated model, CUSUM and CUSUMSQ tests which are developed by (Pesaran, M. H., Shin, 1999) and (Brown, Durbin, and Evans, 1975) are recommended. CUSUM and CUSUMSQ statistics are recursive estimates and they are marked against breakpoints. Visual inspection of recursive estimates provides information about structural breaks or stability of the model. If the CUSUM and CUSUMSQ statistics are within the critical limits drawn at the $5 \%$ significance level, the null hypothesis which states that the model is stable is not rejected.

\section{RESULT AND DISCUSSION}

\subsection{Data base and analytical framework for ARIMA model}

The data focuses on the data of nominal exchange rate movements of US Dollar in terms of Ethiopian birr covering from the period of 1971 to 2020 in annual basis. For this purpose, the data regarding the exchange rate was executed from the World Bank. The sample projection of the respective currencies for a lead time of fifteen years (from 2021 to 2035) were generated by applying the Box-Jenkin's ARIMA method. In univariate Box-Jenkin (UBJ) (Box and Jenkin, 1968; 1994) approach the structure of the past values of the variable is recognized and then the near future is extrapolated on the basis of the past. One of the benefits of Box-Jenkin's approach over other approaches is that it does not depend on any economic presumption and captures the slightest deviation in the data set easily (Makradakis and Hyndman, 1998). Box-Jenkin's methodology is based on the simple assumption of stationarity in the data set but most time series are hardly ever stationary and it is mandatory to convert the series to stationary (maximum up to second level) by differencing the series up to suitable level. If the non-stationarity component is added to a mixed ARMA model, then the general ARIMA ( $p, d, q)$ is obtained by having the form here under:

$$
\ddot{O}_{p}(\beta)(1-\beta)^{d} Y_{t}=C+\hat{e}_{q}(\beta) e_{t}
$$


$\ddot{O} \mathrm{p}(\beta) \mathrm{W}_{\mathrm{t}}=\mathrm{C}+\hat{\mathrm{e}}_{\mathrm{q}}(\beta) \mathrm{e}_{\mathrm{t}}$ which will be non-stationary unless $\mathrm{d}=0$.

The Box-Jenkin methodology has four steps. These are: Identification, estimation, diagnosis and forecasting. During identification step, the sample autocorrelation and partial autocorrelation functions were matched with their theoretical counterparts to identify the tentative model(s). in diagnosis testing of the autocorrelation coefficients of residuals was worked out so that the estimated ARIMA model is adequate. From the models' residuals of each variable, Ljung-Box Q statistics were calculated to examine the hypothesis of randomness and the suitability of ARIMA model to make the reliable forecast. To make forecast equation, equation (3.1) was worked out to get $\mathrm{Yt}$ and et by applying the relation $\mathrm{Wt}=(1-\beta)^{\mathrm{d}} \mathrm{Y}_{\mathrm{t}}$. The reliable estimates of $\mathrm{Y}_{\mathrm{t}+-! \text { (Designated by }}$ $Y_{t}(-!)$ at time $t$ has been considered as conditional expectation of $Y_{t+-!}$ where $t$, is the forecast origin and $-!$ is the lead time of estimates. Error term $e_{t}$ completely dispersed once we forecast for more than q period ahead.

\subsubsection{Analytical result}

The result has been elucidated in brief under the following sub heads:

Descriptive statistics: descriptive statistics of nominal exchange rate of US Dollar for the period from 1971 to 2020 in annual basis is depicted under (Annex of table 1). the table depicts that the mean, standard deviation, minimum and maximum values are $8.414,8.44,2.07$ and 36.15 respectively.

\section{Stationary time series}

To verify the stationarity of the data and to compute the suitable level of differencing, Augmented Dick Fuller test was applied on original and differenced data up to first level. Analysis of the result validated that the variable achieved stationarity after first differencing as exhibited in table 4.1.

Table 3.1: Augmented Dicky Fuller test for Autocorrelation

\begin{tabular}{|c|c|c|c|c||}
\hline \multirow{2}{*}{ Variables } & \multicolumn{3}{|c|}{ ADF TEST } & Remark \\
\cline { 2 - 5 } & With drift & With drift and trend & Without drift and trend & I (0) \\
\hline NEXR & 6.5725 & 3.0414 & 8.2614 & I (1) \\
\hline D(NEXR) & -0.9970 & $-4.4750^{* * *}$ & -0.3292 & \\
\hline
\end{tabular}

Source: own computation, 2021.

\section{Model identification}

In this stage, the sample autocorrelation function with partial autocorrelation function were compared along with their theoretical counterparts (Pankratz, 1983) and it has been discovered that autoregressive (AR) and moving average (MA) process could not surpass the order 2. Keeping into consideration the principle of parsimony, we have applied all the four probable combination of ARIMA models depending on the values of $\mathrm{p}, \mathrm{d}$, $\mathrm{q}$ to choose the suitable order of ARIMA model. The possible combinations ware: $\{(1,1,1),(1,1,2),(2,1,1)$ and $(2,1,2)\}($ see Annex table 3.2).

\section{Estimation of different ordered ARIMA models}

The estimation of different ordered ARIMA models is exhibited in table 4.3. We have picked these values of parameters as the final approximation in those cases where the sum of square (SSE) of disturbance terms was found to be least. In this paper the estimation was executed on the differenced data and to generate forecasts in consonance with the input data, we have performed the inverse of differencing before producing the predictions. The estimation of the model was performed through maximum likelihood method (Box-Jenkin's and Reinsell, 1994, p.225).

\section{Diagnostic testing of differenced ARIMA model}

In diagnostic testing, the selection of best fitted models and its accuracy was confirmed on the basis of various parameters as explained above. A model was considered superior if it has minimum AIC value, minimum SBS value, least sum of square of errors and minimum value of SIGMASQ (volatility). The result of the model had been represented in table 3.3 .

Table 3.3. comparative result from various ARIMA models

$\begin{array}{llllll}\text { variable } & \text { estimate } & \text { ARIMA }(1,1,1) & \text { ARIMA }(1,1,2) & \text { ARIMA }(2,1,1) & \text { ARIMA }(2,2,2) \\ \text { NEXR } & \text { Sum of squares } & 58.5666 & 65.6575 & 55.34 & 55.017 \\ & \text { AIC } & 3.1764 & 3.2718 & 3.1268 & 3.1342 \\ & \text { SBC } & 3.2922 & 3.3876 & 3.24 & 3.2500 \\ & \text { SIGMASQ (volatility } & 1.195 & 1.3399 & 1.1200 & 1.1228\end{array}$

Source: own computation, 2021.

Table 4.3. shows that the values of SSE, AIC, SBC and SIGMASQ (volatility of the variable) of all the four variables. The inspection of the table confirmed that in the case of the model $(2,1,1)$, AIC, SBC and SIGMASQ values are minimum which is $3.12,3.24$ and 1.1200 respectively compared to other competing models. Hence, the $\operatorname{ARIMA}(2,1,1)$ model was selected to forecast the exchange rate. Figure 4.1. clearly shows that the correlogram of the residual's autocorrelation functions of the model $(2,1,1)$. 


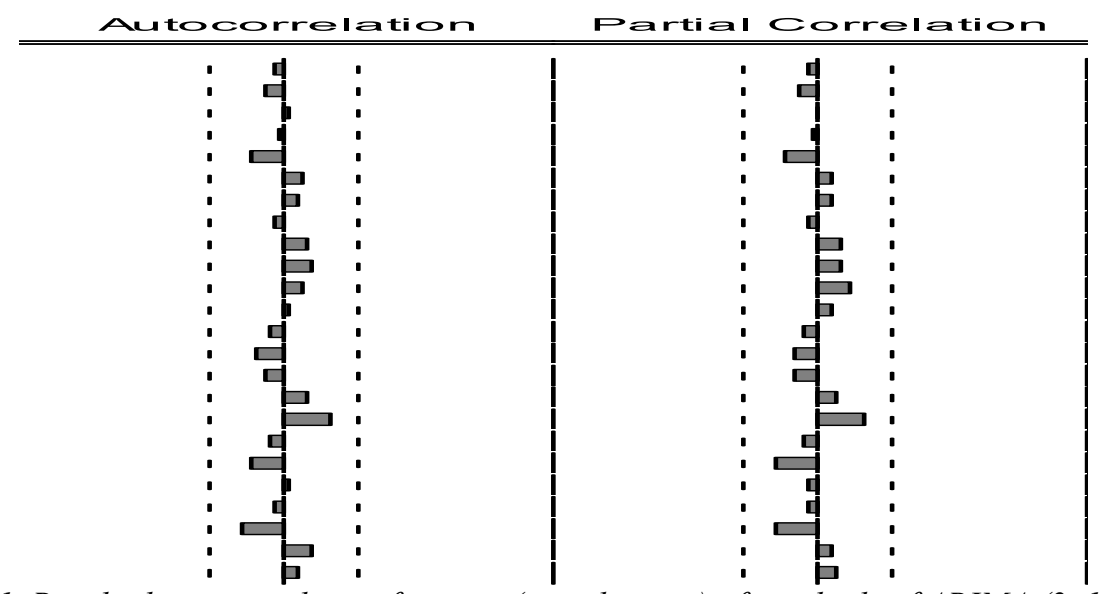

Figure 3.1. Residual autocorrelation function (correlogram) of residuals of ARIMA $(2,1,1)$ model

Examination of table 3.4 below reveals that in the year 2021, the prediction of one USD in terms of birr would be on average 37.4041 birr which is forecasted to rise to 43.07898 birr in the year 2022 and finally expected to be 65.1967 birr by the year 2035 .

This result is substantiated by the graphical representation in figure 4.2. In addition to the aforementioned point of forecasting, Interval forecasts at 95 percent confidence bounds within which the forecasts are expected to lie. The forecasts' floor and ceiling were set by these lower and upper limits. (Figure 3.3).

Table 3.4: Forecasted values of NEXR using ARIMA $(2,1,1)$ model

\begin{tabular}{|l|l|l|l|l|l|l|l|l|l|l|l|l|l|l|l|}
\hline Year & 2021 & 2022 & 2023 & 2024 & 2025 & 2026 & 2027 & 2028 & 2029 & 2030 & 2031 & 2032 & 2033 & 2034 & 2035 \\
\hline $\begin{array}{l}\text { NEXR } \\
\text { (forecasted) }\end{array}$ & 37.40 & 43.07 & 44.11 & 48.75 & 49.59 & 53.38 & 54.07 & 57.17 & 57.74 & 60.28 & 60.74 & 62.81 & 63.19 & 64.89 & 65.19 \\
\hline
\end{tabular}

Source: own computation, 2021.

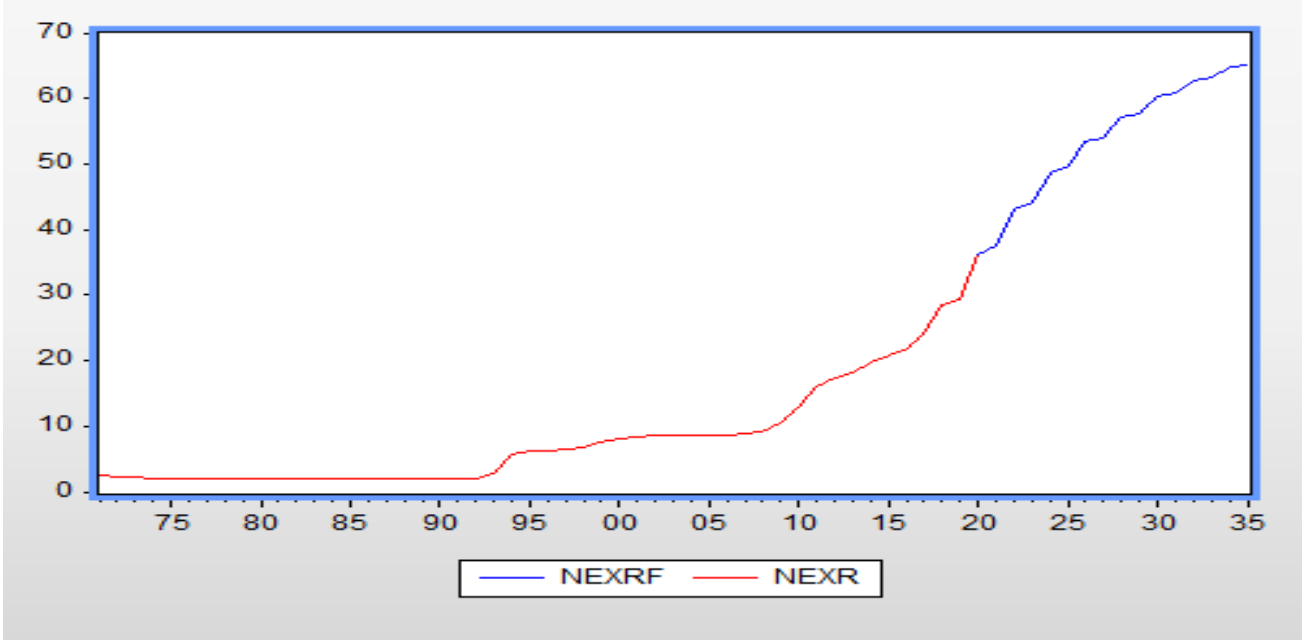

Figure 3.2: joint estimation of the existing and forecasted NEXR of ARIMA model 


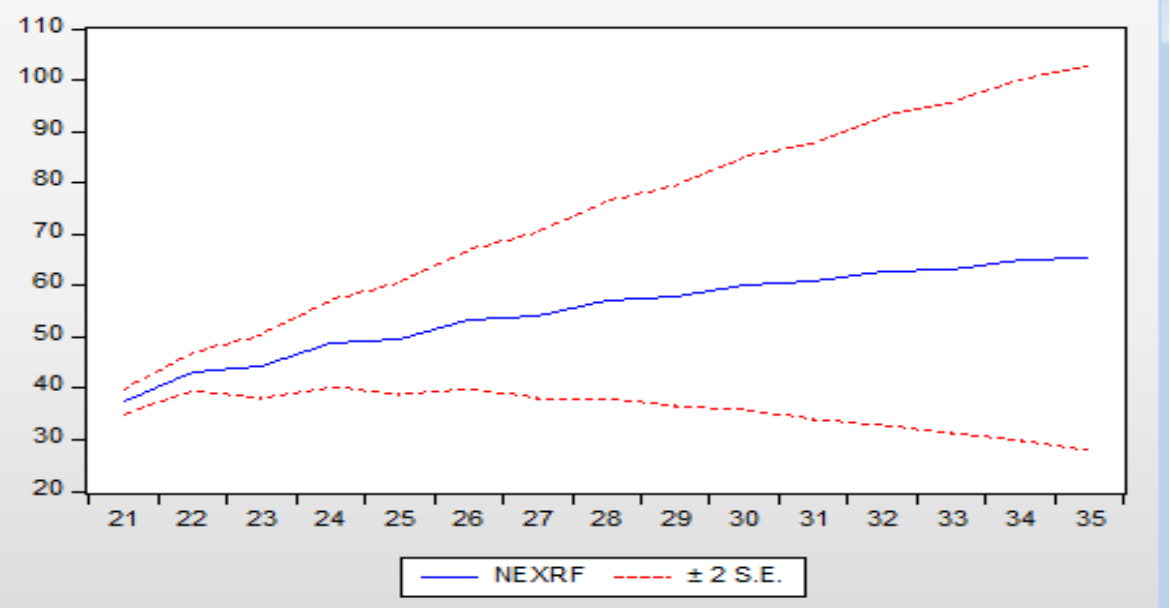

Figure 3.3: the forecast of ARIMA $(2,1,1)$ model showing upper and lower limit (2021 to 2035)

To summarize, this research aimed to assess the model's forecasting capacity in the setting of a developing country (Ethiopia) that operates under a flexible exchange rate regime. To develop US dollar in terms of Ethiopia birr projections, the Auto Regressive Integrated Moving Average (ARIMA) model proposed by Box-Jenkins was applied to stationary data with appropriate mixes of autoregressive and moving average processes. The model prediction indicated that the exchange rate devaluation will show an increasing trend over the next projected years. This forecast will give the government, policymakers, corporations, currency dealers, and others guidance on how to build policies in light of forecasts, as well as how to generate forecasts using the appropriate models.

\subsection{ARDL Model Result and Estimation}

This section begins with descriptive statistics of the variables. This is followed by analyzing nominal exchange trend in Ethiopia, while the time series property using test statistics of Augmented Dickey Fuller (ADF) to provide the basis for the analysis was also considered. Table 3.5 reports the descriptive values of all the variables employed and shows that the mean value of real domestic product, nominal exchange rate, import, export and inflation rate is $1.92 \mathrm{E}+10,8.148669,3.89 \mathrm{E}+09,1.07 \mathrm{E}+09$ and 9.460127 .

The series that measures the highest level of discrepancy as shown in the standard deviation result is real GDP, while nominal exchange rate shows the lowest level.

Skewness indicates the rate of asymmetry or discrepancy of the variables. Accordingly, RGDP, NEXR, IMPORT, EXPORT, and INFLATION have long right tail. This is because the variables exhibit positive values.

Kurtosis measures the pawedness and flatness of the series. The result shows that only EXPORT is platykurtic relative to its normal distribution because its value is less than 3 . While other variables have their kurtosis value greater than 3, this shows that the peak of their distributions are greater than normal, thus, referred to as leptokurtic distribution. Jarque-Bera statistical test indicates the variables that are normally distributed as it measures the differences in the skewness and kurtosis. The result shows that Jarque-Bera statistic rejects the null hypothesis of no normal distribution for all the variables. Thus, it is concluded that they are all normally distributed ( $p$-value of all variables are significant).

\begin{tabular}{lcc}
\multicolumn{2}{c}{ Table 3.5: descriptive statistics } & \\
\multicolumn{1}{c}{ statistics } & RGDP & NEXR \\
Mean & $1.92 \mathrm{E}+10$ & 8.148669 \\
Median & $1.20 \mathrm{E}+10$ & 6.691200 \\
Maximum & $6.23 \mathrm{E}+10$ & 28.45000 \\
Minimum & $7.76 \mathrm{E}+09$ & 2.070000 \\
Std. Dev. & $1.52 \mathrm{E}+10$ & 7.078897 \\
Skewness & 1.509247 & 1.183532 \\
Kurtosis & 4.105426 & 3.525069 \\
Jarque-Bera & 18.08322 & 10.28771 \\
Probability & 0.000118 & 0.005835 \\
Sum & $8.06 \mathrm{E}+11$ & 342.2441 \\
Sum Sq. Dev. & $9.51 \mathrm{E}+21$ & 2054.542 \\
Observations & 42 & 42
\end{tabular}

IMPORT
$3.89 \mathrm{E}+09$
$1.11 \mathrm{E}+09$
$1.50 \mathrm{E}+10$
$4.17 \mathrm{E}+08$
$4.75 \mathrm{E}+09$
1.318445
3.244319
12.27254
0.002163
$1.64 \mathrm{E}+11$
$9.27 \mathrm{E}+20$
42

42

EXPORT
$1.07 \mathrm{E}+09$
$4.82 \mathrm{E}+08$
$3.42 \mathrm{E}+09$
$1.68 \mathrm{E}+08$
$1.06 \mathrm{E}+09$
1.159964
2.658527
9.622670
0.008137
$4.49 \mathrm{E}+10$
$4.64 \mathrm{E}+19$
42

INFLATION

9.460127

7.879375

44.39128

$-9.808765$

10.68876

1.083737

5.121023

16.09419

0.000320

397.3253

4684.234

42

Source: own computation, 2021. 


\section{Residuals Diagnostic Test}

Before beginning the estimation procedure, a diagnosis test of the residual of several post estimation tests was required. As a result, the following tests were run, and the results are shown below. The Breusch-Godfrey serial correlation LM test was used to examine whether the data and variables were stable and cascaded using the residual test. The sequence correlation findings for the Breusch-Godfrey test are shown in Table 3.6. Because the P-Value was greater than $5 \%$ significance levels $(0.6898>5 \%)$, we were unable to reject the null hypothesis of no sequence correlation, and we concluded that the model and data did not have categorization or sequence correlation. In table 3.7. the test result of Ramsey RESET test for model specification indicates that the p-value is larger than 0.05 implying there is no model specification error.

Table 3.6 test for serial correlation

Breusch-Godfrey Serial Correlation LM Test:

\begin{tabular}{|c|c|c|c|}
\hline F-statistic & 0.162433 & Prob. F $(2,30)$ & 0.6898 \\
\hline Obs*R-squared & 0.215411 & Prob. Chi-Square (2) & 0.6426 \\
\hline
\end{tabular}

Table 3.7. model specification test (Ramsey RESET test)

\begin{tabular}{lccc}
\hline & Value & df & Probability \\
\cline { 2 - 4 } t-statistic & 1.075227 & 30 & 0.2908 \\
F-statistic & 1.156113 & $(2,30)$ & 0.2908
\end{tabular}

The test for heteroscedasticity in the residuals is checked using Breusch-Pagan-Godfrey test for heteroscedasticity and the p-value is larger than 0.05 that is $p$-value $=0.9889$ (table 4.8 ) which rejects the null hypothesis of "there is no constant variance among the residuals" indicating that the model has constant variance. Hence, the model is good to estimate.

Table 3.8. test for heteroscedasticity

Heteroskedasticity Test: Breusch-Pagan-Godfrey

\begin{tabular}{llll}
\hline \hline F-statistic & 0.198767 & Prob. F (8,31) & 0.9889 \\
Obs*R-squared & 1.951677 & Prob. Chi-Square (8) & 0.9825 \\
Scaled explained SS & 1.920457 & Prob. Chi-Square (8) & 0.9834
\end{tabular}

Figure 4.4. displays the stability diagnosis test of the CUSUM test and the CUSUM square test for the variables considered. It is clear from the CUSUM and CUSUM of squares test that since the blue line does not exceed the 5\% significance line (red line), the variables are very stable during the period under study. Therefore, we believe that all variables and data are well adapted.
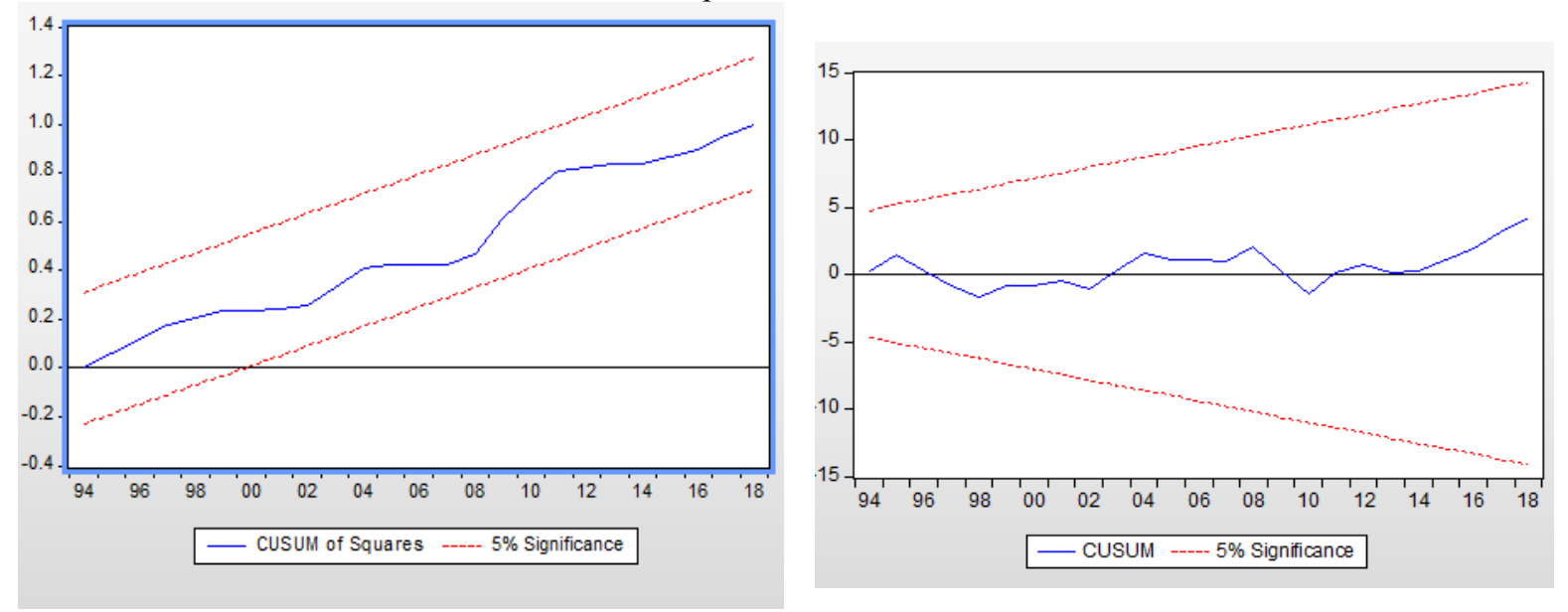

Figure 3.4: CUSUM square and CUSUM tests

The next section reports the empirical results and interpretations of the estimated model that apply Bound testing approach for cointegration. The results of unit-root test that has been performed by applying test of stationarity, that is, ADF for the application of ARDL. After unit-root analysis, there is a need to scrutinize the response of exchange rate to output along with the combination of import, export and inflation variables. 
Table 3.9: results of unit-root tests

\begin{tabular}{|c|c|c|c|c|}
\hline variable & $\begin{array}{l}\text { Constant/ constant \& } \\
\text { trend }\end{array}$ & Level (ADF) & $\begin{array}{l}1^{\text {st }} \text { difference } \\
(\mathrm{ADF})\end{array}$ & $\begin{array}{l}\text { Order } \\
\text { integration }\end{array}$ \\
\hline LNRGDP & Constant \& trend & -0.2363 & $-4.0894 * * *$ & $\mathrm{I}(1)$ \\
\hline LNNEXR & Constant \& trend & -2.8742 & $-4.2724 * * *$ & I (1) \\
\hline LNIMPORT & Constant \& trend & -1.1516 & $-10.0929 * * *$ & I (1) \\
\hline LNEXPORT & Constant \& trend & -1.7621 & $-5.5251 * * *$ & I (1) \\
\hline INFLATION & Constant \& trend & $-5.2205 * * *$ & $-8.7591 * * *$ & $\mathrm{I}(0)$ \\
\hline
\end{tabular}

Note: $*, * *, * * *$ indicate the rejection of null hypothesis of unit-root at $10 \%, 5 \%$ and $1 \%$ level of significance, respectively.

Table 3.9 reveals the result of the unit root; it shows that variables such as nominal inflation rate was integrated at order zero, while real gross domestic product, exchange rate, import and export were found to be stationary at first difference. The result of the unit root provides the basis for the study to use autoregressive distributed lag for both short- and long- run estimation of the model.

Table 4.10. reveals the lag selection criterion suggested by LR, FPE, AIC, SC, HQ. The result shows that the optimum number of lag suitable for this analysis is 2 . The suggestion is taken into consideration when analyzing ARDL model.

Table 3.10: lag length selection

\begin{tabular}{ccccccc}
\hline \hline Lag & LogL & LR & FPE & AIC & SC & HQ \\
\hline \hline 0 & -201.9415 & NA & 0.021445 & 10.34707 & 10.55818 & 10.42340 \\
1 & -13.20718 & 320.8483 & $6.04 \mathrm{e}-06$ & 2.160359 & $3.427018^{*}$ & $2.618343^{*}$ \\
2 & 14.39184 & $40.01858^{*}$ & $5.64 \mathrm{e}-06^{*}$ & $2.030408^{*}$ & 4.352617 & 2.870045 \\
\hline \hline
\end{tabular}

Note: * Indicates the selected lag order by criterion, Likelihood Ratio test (LR), Final Prediction Error criteria (FPE), Akaike Information Criteria (AIC), Schwarz Information Criteria (SC) and Hanna-Quinn Information Criterion

The Akaike Information Criteria is used to select the lag length.

The bounds test result in Table 3.11 shows that the F-statistic (11.682) is beyond all the significance levels. It, therefore, indicates clearly the long-run relationship among the variables.

Table 3.11: Bounds test of cointegration

F-Bounds Test

\begin{tabular}{lcrrr}
\hline \hline Test Statistic & Value & Signif. & I (0) & I (1) \\
\hline \hline F-statistic & 11.68261 & $10 \%$ & 2.45 & 3.52 \\
K (number of regressors) & 4 & $5 \%$ & 2.86 & 4.01 \\
& & $2.5 \%$ & 3.25 & 4.49 \\
& & $1 \%$ & 3.74 & 5.06
\end{tabular}

After determining the existence of long-run relationship among the series by applying the bounds testing approach, there is a need to define the long-run coefficients of ARDL estimation. The derived results that reflect the reaction of real output to the series of explanatory variables along with "nominal exchange rate" are reported in Table (3.12). 
Table 3.12: ARDL Long-Run (a) and short-run (b) relationships of the Model

\begin{tabular}{crrrr}
\hline \hline Variable & Coefficient & Std. Error & t-Statistic & Prob. \\
\hline \hline & Long-run relationship (a) & & \\
\hline LNNEXR & $0.142600^{* *}$ & 0.068938 & 2.068507 & 0.0470 \\
LNIMPORT & $0.532534^{* * *}$ & 0.093166 & 5.715960 & 0.0000 \\
LNEXPORT & 0.045369 & 0.091881 & 0.493784 & 0.6249 \\
\hline INFLATION & $-0.002741^{* *}$ & 0.004030 & -0.680092 & 0.0155 \\
\hline & Short-run relationship (b) & & & \\
\hline & & & 0.0011 \\
C & 2.790821 & 0.776468 & 3.594253 & 0.0001 \\
LNRGDP (-1)* & $-0.251934^{* * *}$ & 0.054914 & -4.587751 & 0.0545 \\
LNNEXR** & 0.035926 & 0.017979 & 1.998178 & 0.0005 \\
LNIMPORT (-1) & $0.134163^{* * *}$ & 0.034712 & 3.865063 & 0.6234 \\
LNEXPORT $* *$ & 0.011430 & 0.023044 & 0.496022 & 0.5047 \\
INFLATION (-1) & -0.000690 & 0.001023 & -0.674983 & 0.2974 \\
D(LNIMPORT) & 0.036229 & 0.034186 & 1.059762 & 0.0111 \\
D(INFLATION) & $-0.001610^{* *}$ & 0.000596 & -2.702422 & 0.0212 \\
D(INFLATION (-1)) & $-0.001480^{* *}$ & 0.000610 & -2.427190 & 0.0000 \\
\hline CointEq (-1)* & 0.251934 & 0.031023 & & \\
\hline \hline
\end{tabular}

Note: $* * *, * *$ denote the significance level at $1 \%$ and $5 \%$ level of significance, respectively.

The theoretical justification of estimated results requires brief explanation of previous literature. On theoretical ground, currency devaluation leads to increase in net exports that may result in expansion of output (Dornbush's, 1988; Keynesian, 1931). On empirical side, some studies (Miteza, 2006; and Kalyoncu, et al, 2008; Muhammad N. and Ejaz G., 2017) follow the expansionary output hypothesis that is consistent with conventional literature. The long-run result of this study is in line with that of theoretical and empirical literature. The short-run findings of the analysis evaluate that currency devaluation (nominal exchange rate) has no significance relevance to affect economic growth.

The model is estimated in log transformed form, with calculating coefficient values of "nominal exchange rate" of 0.1426 , which is significant at the 5\% level. A 1 percent increase in nominal exchange rate will increase the real gross domestic product by 0.1426 percent in the long-run. This indicates that exchange rate has a long-run expansionary effect on economic growth. This finding is consistent with the findings of other empirical findings of (Jones and Olken, 2008; Gala, 2007; Rodrik, 2014). When managed carefully, the exchange rate can be a critical policy tool for stimulating export growth since Ethiopia's export-to- GDP is one of the lowest ratios in the world i.e., 3.89\% of GDP (IMF 2018). The manufacturing sector has been associated with strong economic growth in developing countries and still remains at the heart of catch-up development. Countries with competitive or undervalued currencies tend to experience more rapid manufacturing growth yet Ethiopia's manufactured exports remain below $10 \%$ of total exports (AfDB 2017, p 7). In developing countries, a sizable devaluation facilitates the expansion of the manufacturing sector by encouraging firms to enter new export markets and new export sectors (Freund and Pierola, 2012).

Although the coefficients of imports and exports are both positive, the variable export is insignificant in terms of influencing economic growth. At a 1\% significance level, the coefficient of import is statistically significant. In the long run, a $1 \%$ increase in imports will result in a 0.532 percent increase in real GDP. This positive relationship between import and real GDP of Ethiopia was consistent with the previous empirical studies of (Adenutsi, 2008; Charles R. et al, 2019). This empirical study's result confirms the positive contribution for import-dominant sectors, which have direct growth impacts on Ethiopia's overall economic growth. In the case of Ethiopia, the major part of the economy is dependent on the import of raw material, intermediate or capital goods, particularly oil, machinery and such other materials which have significant contribution to the growth of real GDP. Some conditions that are often associated with official imports to developing countries, Ethiopia inclusive, might be directly favorable to initiating higher levels of industrial performance as well as economic growth.

Another explanatory variable that is negatively related is the rate of inflation, which indicates that a $1 \%$ increase in the rate of inflation in the long run leads to a 0.27 percent reduction in real GDP in the case of Ethiopia. The outcome is consistent with the findings of Anthony O. et al (2020).

Table 4.11 (b) explains the short-run relationship between Ethiopia's economic growth and the exchange rate, which shows whether the exchange rate is deterministic or not. To begin with, the significance of the error correction mechanism (ECM) result and the negative sign of the coefficient support the establishment of cointegration among variables in this study. This coefficient is -0.251 , implying that approximately 25.1 percent of 
the previous year's disequilibrium is corrected in the current year. As a result, in the long run, the error correction model (ECM) adjusts slowly to changes.

The main explanatory variable, "nominal exchange rate," has the expected sign and is positively related to RGDP; however, it is not significant, implying that it has no significant effect on RGDP in the short run. Furthermore, export has no significant effect on RGDP in the short run, whereas inflation rate (INFLATION) and its lag period (INFLATION (-1)) have a significant and negative effect on real gross domestic product in the short run. In the short run, the lag period of variable import (IMPORT (-1)) has a significant and positive effect on RGDP, whereas the instantaneous period of import has no significant effect on RGDP.

\section{CONCLUSION}

A competitive exchange rate would help to create an environment conducive to manufacturing-led structural transformation, sustained growth acceleration, and improved external balance. Empirical analysis using Ethiopian data provides fairly strong evidence to support the proposition that devaluation can stimulate exports, improve the external balance, boost economic growth, and promote industrialization-driven structural transformation. In other words, a birr devaluation will play an important role in promoting expenditure switching and long-term development (i.e., the growth of efficient export-oriented and import-substituting industries). However, devaluation would involve key macroeconomic trade-offs including the higher cost of imported capital equipment and increase in external debt stock and servicing when expressed in local currency.

Using the Autoregressive Distributed Lag (ARDL) Model, this study examines the impact of the Ethiopian exchange rate on economic development between 1977 and 2018. The findings show that the nominal exchange rate has a statistically significant positive impact on Ethiopian economic growth. Long-term coefficients show that imports have a large positive effect on real GDP, whereas inflation has a significant negative effect on real GDP. Despite the fact that devaluation benefits the economy, the exchange rate has the disadvantage of feeding inflation, which reduces real GDP. In addition, the ARIMA model was used to forecast the exchange rate. This forecasting is important for monetary policy formulation. The forecast will provide guidance to the government, policymakers, corporations, currency dealers, and others on how to build policies based on forecasts.

\subsection{Recommendation}

A more depreciated nominal exchange rate would be a major step forward, but it is not a panacea. Because exports are also constrained by binding capacity and the business environment constraints, supply side factors must be addressed concurrently. The high cost of doing business is one of the major impediments to Ethiopia's export development that ultimately hampers economic growth. As a result, a one-time exchange rate adjustment will be insufficient to address the structural bottlenecks that impede exports, and necessitating a more comprehensive policy package to improve supply response to devaluation. This would include efforts to overcome significant obstacles in the still-challenging business climate (e.g., trade logistics, access to capital and land, infrastructure shortfall, cumbersome customs procedures, skills gap), as real GDP growth and diversification are critical.

One of the government's macroeconomic challenges is price stability. Because devaluation may cause inflation to rise. The IMF estimates inflation pass-through of devaluation is around $0.43 \%$ for every $1 \%$ devaluation, so for every $1 \%$ devaluation (to the US\$), inflation can be expected to rise $0.43 \%$ in the short term as import costs rise. Hence, the government must prioritize maintaining a single-digit inflation rate. As a result, the policy implications of using fiscal and monetary measures concurrently must be investigated.

\section{References}

Acar, M. (2000). Devaluation in Developing Countries: Expansionary or Contractionary? Journal of Economic and Social Research, 2(1), pp.59-83.

AfDB, OECD, UNDP (2017). African Economic Outlook.

Ahiabor, G., and Amoah, A. (2019). Examining the Effect of Real Effective Exchange Rate Volatility on Economic Growth: Evidence from Ghana. Journal of Economics and Economic Education Research, 20(1), 1-14.

Agus, S., Ignatius, A., \& Long, V. (2018). An evidence analysis of the exchange rate disconnects puzzle in Indonesia. Journal of Business Management and Economic Research, 2(5), 47- 60. Available at: https://doi.org/10.29226/tr1001.2018.33.

Ahmad, A., Ahmad, N., \& Ali, S. (2018). Exchange rate and economic growth in Pakistan. Journal of Basic and Applied Scientific Research, 3(8), 740-746.

Anthony Olugbenga Adaramola and Oluwabunmi Dada (2020). Impact of inflation on economic growth: evidence from Nigeria. Investment Management and Financial Innovations, 17(2), 1-13. doi:10.21511/imfi.17(2).2020.01

Balassa, Bela (1984). Adjustment Policies in Developing Countries: A Reassessment". World Development, Vol. 12, pp. 955- 972.

Beakal Tafesse (2019). The impact of currency devaluation on economic growth: the costs and benefits on 
Ethiopian economy, MSc thesis, Addis Ababa.

Barguellil, A., Ben-Salha, O., \& Zmami, M. (2018). Exchange rate volatility and economic growth. Journal of Economic Integration, 33(2), 1302-1336.

Befikadu, D. and Kibere, M. (1994). Post devaluation of the Ethiopian economy. From stagnation to stagflation, in Makonnen Tadesse and Abdula Hamid Bedri Kello the Ethiopian economy problem of adjustment, proceeding of the second annual conference on Ethiopian economy.

Box, G. e. p. Jenkins, G. M. and Reinsell, G. C, (1994). Time series analysis forecasting and control Englewood Cliffs, N. J, Prentice - Hall.

Box, G. e. p. Jenkins, G. M., (1998). Some recent advance in forecasting and control. Applied statistics, $91-109$.

Brown, R., Durbin, J., and Evans, J. (1975). Techniques for testing the constancy of regression relationships over time. Journal of the Royal Statistical Society, 37(2), 149-192. https://doi.org/10.2307/2984889

Bautista, Romeo M., Helen Hughes, David Morawetz, Francisco E. Thoumi (1981). Capital Utilization in Manufacturing. A World Bank Research Publication. New York (Oxford University- Press).

Branson, William H. (1986). Stabilization, Stagflation and Investment Incentives: The Case of Kenya 1979-80". In: Sebastian Edwards, Liaquat Ahamed (eds.), Economic Adjustment and Exchange Rates in Developing Countries. Chicago (University of Chicago Press), pp. 267-293.

Cooper, Richard N. (1971). Currency Devaluation in Developing Countries. Princeton University, Essays in International Finance, 86. Princeton.

Damghani, K. K., Taghaviferd, M. T., and Moghaddam, R. T. (2009). Decision making under uncertainty and risky situations. In Enterprise Risk management symposium monograph society of Actuaries-Schaumburg, Illinois (15).

Diaz Alejandro, Carlos F. (1963). A Note on the Impact of Devaluation and the Redistributive Effect". Journal of Political Economy, Vol. 71, pp. 577-580.

Edwards, Sebastian (1985a). Are Devaluations Contractionary? National Bureau of Economic Research, Working Paper, 1676. Cambridge, Mass.

Engle, R. F., and Granger, C. W. J. (1987). Co-Integration and Error Correction: Representation, Estimation, and Testing. Econometrica, 55(2), 251. https://doi.org/10.2307/1913236

Eun, c. s., and Resnick, B. G. (2018). International Financial management 4E. Tata McGraw-Hill Education

Fratzscher M., Marco Lo Duca and Roland Straub (2014). ECB Unconventional monetary Auctions: market impact, international spillovers and transmission channels: IMF $15^{\text {th }}$ annual conference, Washington DC, USA.

Hopper, G. p. (1997). What determines the exchange rate: economic factors or market sentiments. Business review, $5,17-29$

Hussaini, U., Aguda Niyi, A., \& Davies, N. O. (2018). The effects of exchange rate volatility on economic growth of West African English-speaking countries. International Journal of Academic Research in Accounting, Finance and Management Sciences, 8(4), 131-143.

Hanson, James A. (1983). Contractionary Devaluation, Substitution in Production and Consumption, and the Role of the Labor Market". Journal of International Economics, Vol. 14, pp. 179-189.

Hussain, Z. J., and Farooq, M. (2009). Economic growth and exchange rate volatility in the case of Pakistan. Pakistan Journal of Life and Social Sciences, 7(2), 112-118.

IMF (2018). The Federal Democratic Republic of Ethiopia: 2017 Article IV Consultation-Press Release; Staff Report; and Statement by the Executive Director for The Federal Democratic Republic of Ethiopia. January 24, 2018. http://www.imf.org/en/Publications/CR/Issues/2018/01/24/The-Federal-Democratic Republic-ofEthiopia-2017-Article-IV-Consultation-Press-Release-Staff-45576

IMF (2018b). World Economic Outlook April 2018.

IMF, 2010. The Federal Democratic Republic of Ethiopia: Second Review of the Arrangement under the Exogenous Shocks Facility.

Islam, Shafiqul (1984). Devaluation, Stabilization Policies and the Developing Countries". Journal of Development Economics, Vol. 14, pp. 37-60.

Johansen, Soren. (1991). Estimation and Hypothesis Testing of Cointegration Vectors in Gaussian Vector Autoregressive Models. Econometrica, 59(6), 1551. https://doi.org/10.2307/2938278

Johansen, Søren, and Juselius, K. (1990). Maximum Likelihood Estimation and Inference on Cointegration With Applications to the Demand for Money. Oxford Bulletin of Economics and Statistics, 52(2), 169-210. https://doi.org/10.1111/j.1468- 0084.1990.mp52002003.x

Kendall, P. (2018). Globalization, trade liberalization and the Csme. 1-30. Retrieved $10^{\text {th }}$ September ,2014 from http://www.caribank.org/uploads/publications-reports/staff papers/globalization\%20and\%20the \%20cs MEA.pdf.

Korkmaz, S. (2013). The effect of exchange rate on economic growth: Balikesir University: ResearchGate.

Krugman, Paul, Lance TAYLOR [1978], "Contractionary Effects of Devaluation". Journal of International 
Economics, Vol. 8, pp. 445-456.

Lencho, D. (2013). The Effect of Exchange Rate Movement on Trade Balance in Ethiopia, Tokyo University, 2013.

Lizondo, J. Saul, Peter J. Montiel (1988). Contractionary Devaluation in Developing Countries: An Analytical Overview. IMF Working Paper WP/88/51. Washington.

Makridakis, S. C. and Hyndman, R. J. (1998). Forecasting methods and applications. New York: John Willey \& Sons.

Mori, K., Asid, R., Lily, J., Mulok, D., \& Loganathan, N. (2012). The effect of exchange rates on economic growth: Empirical testing on nominal versus real. The IUP Journal of Financial Economics, 10(1), 7-17.

Muhammad N. and Ejaz G. (2017). Currency depreciation and output nexus: evidence from Pakistan, Pakistan Institute of development economics, Islamabad.

Musyoki, D., Pokhariyal, G. P., and Pundo, M. (2012). The Impact of real exchange rate misalignment on economic Growth: Kenyan evidence. Research Journal of Finance and Accounting, 7(1), 59-75.

Nguyen, H. (2014). Real exchange rate and export growth in Ethiopia. Background Paper for the World Bank's Third Ethiopia economic update. World Bank.

Pesaran, M. H., Shin, Y. (1999). An autoregressive distributed lag modelling approach to cointegration analysis. In Econometrics and Economic Theory in the 20th Century: The Ragnar Frisch Centennial Symposium. (pp. 1-31). https://doi.org/10.1017/CCOL521633230

Peter, Y. M., \& Isaac, K. O. (2017). Real exchange rate and economic growth in Ghana. MPRA Paper No. 82405. Rastegrar, M., and Rasekhi, s. (2013). An application of Neural Network and Hidden Markov Model: A case study for Euro Dollars exchange rate. International journal of economics and management engineering. 3(5), 169175.

Reisen, Helmut (1988). The Interaction between the Exchange Rate and the Public Budget in Major Developing Debtor Countries. Paper presented at the 44th Congress of the International Institute of Public Finance, Istanbul (mimeo).

Tanzi, Vito [1977], "Inflation, Lags in Collection, and the Real Value of Tax Revenue". IMF Staff Papers, Vol. 24, pp. 154- 167.

Taye, H. (1999). The Impact of Devaluation on Macroeconomic Performance: The Case of Ethiopia. Journal of Policy Modeling.

Umaru, H., A, A. N., and Davies, N. O. (2018). The Effects of Exchange Rate Volatility on Economic Growth of West African English-Speaking Countries. International Journal of Academic Research in Accounting, Finance and Management Sciences, 8(4), 131-143. https://doi.org/10.6007/IJARAFMS/v8-i4/5470

Williamson, John (1983). The Open Economy and the World Economy. New York (Basic Books).

Table 3. 2: possible combination of ARIMA model

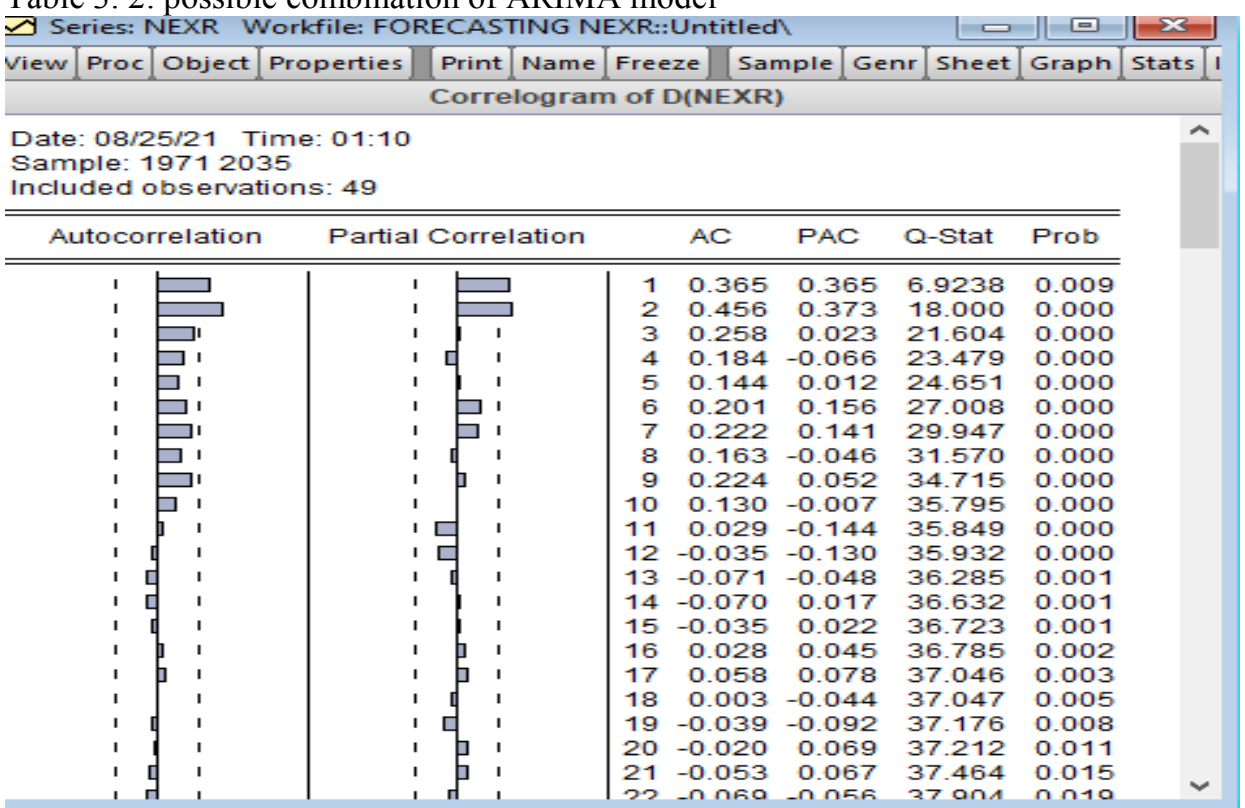

